\author{
Jurnal segara JURNAL SEGARA \\ http://ejournal-balitbang.kkp.go.id/index.php/segara \\ ISSN : 1907-0659 \\ e-ISSN : 2461-1166 \\ Accreditation Number: 766/AU3/P2MI-LIPI/10/2016
}

\title{
IDENTIFICATION OF RECLAMATION AREA IN ANCOL OF NORTH JAKARTA USING RESISTIVITY METHOD
}

\author{
Dino Gunawan Pryambodo"), Joko Prihantono"1), Syaiful Imam²), \\ Abdurrahman Wafi $^{2)}$, \& Panganggit Sasmito ${ }^{2)}$ \\ 1)Marine Research Centre, Ministry of Marine Affairs and Fisheries, Indonesia \\ Jl. Pasir Putih 2, Ancol Timur Jakarta 14430, \\ 2)PT. ANDALAN TUNAS MANDIRI
}

Received: 17 December 2020; Revised: 31 August 2021; Accepted: 31 August 2021

\begin{abstract}
The coastal reclamation area is an expansion of coastal areas through technical engineering to develop new land areas. Identification of the reclamation area can be performed by detecting subsurface imaging using the resistivity method. This study used a multi-electrode (multichannel) resistivity imaging method. The resistivity imaging results show a good response of subsurface resistivity and successfully identified reclamation area with low resistivity $<27.8 \Omega \mathrm{m}$ in almost the study area. Its depth varies from 4 meters to 30 meters. The reclamation results are composed of loose rock that has not been fully compacted, so it has not been well consolidated. As a result, it will experience land subsidence if overload.
\end{abstract}

Keywords: Reclamation, subsidence, Ancol, resistivity. 


\section{INTRODUCTION}

The coastal urban areas tend to undergo rapid changes, causing various problems such as increasing land needs for housing, industry, trade and services, ports, warehousing, marine tourism, and facilities and infrastructure. So, it needs to be expanded through coastal areas reclamation (Permen PU, 2007).

The coastal reclamation area is an expansion of coastal areas through technical engineering to develop new land areas. Coastal reclamation areas fall into the category of areas located on the coast, where growth and development both socially, economically, and physically are strongly influenced by the body of seawater (Edyanto, 2016).

Ancol area is located in Ancol village, Pademangan sub-district, North Jakarta (Figure 1), and was established in the 17th century. At that time, The Governor-General of the Dutch East Indies, Adriaan Valckenier, had a beautiful resting house by the beach. Over time, the area then developed into a tourist attraction (Restu, 2010).

The Government Regulation Number 51 of 1960 concerning The Allocation and Use of Ancol Land (PP 51/1960) President Sukarno designated the Ancol area as a tourist area through the Ancol project. As for the implementation of reclamation in the Ancol Project, the Governor of DKI Jakarta issued a decree of the Governor of DKI Jakarta Number 812 the Year 1980 (SK 812/1280) about the implementation of the Ancol Reclamation Project on July 26, 1980.

The resistivity method is one of the geophysics methods that aims to map the soil's subsurface based on the electrical properties of rocks (Syamsul Amien,
2016). This study used a multi-electrode (multichannel) resistivity imaging method (Barker,1981) to map the soil resistivity of the Ancol area. Then the subsurface mapping results will be used to identify the existence of the reclamation land area in Ancol of North Jakarta.

\section{METHODOLOGY}

\section{Geology of Jakarta Area}

Generally, the Jakarta Basin is built by tertiary, quaternary, and recent sedimentary rocks. Tertiary rocks are considered the bottom of the groundwater basin because they are massive (Figure 2). Groundwater reserves in this basin are generally stored in quaternary rock (confined aquifer) and very young alluvial deposits (unconfined aquifer). Subsidence naturally occurs in young rocks (recent) because generally, these rocks have not been compacted and are accelerated by loading, particularly subsidence in North Jakarta. Meanwhile, subsidence in older rocks can occur due to anthropological factors, including excessive groundwater extraction and loading in areas where industrial activities are quite active. Young rocks are also very susceptible to seawater intrusion if exploitation of shallow groundwater exceeds the groundwater balance. (Delinom, 2015)

Quaternary deposits are volcanic alluvium fan units, coastal alluvium units, and rivers. The three units are related. The thickness of the deposit is estimated to be around $65 \mathrm{~m}$ (in the present Ciputat area) to $300 \mathrm{~m}$ (in the present Jakarta Kota area). The bedrock is estimated to be claystone, marl with Pliocene coral limestone inserts. The quaternary deposits in the study area are located unconformity above the tertiary sedimentary bedrock (Martodjodjo 1984). Quaternary deposits are formed by Plio-Pleistocene (1-2 million years ago) to recent rock units, with lithology in the

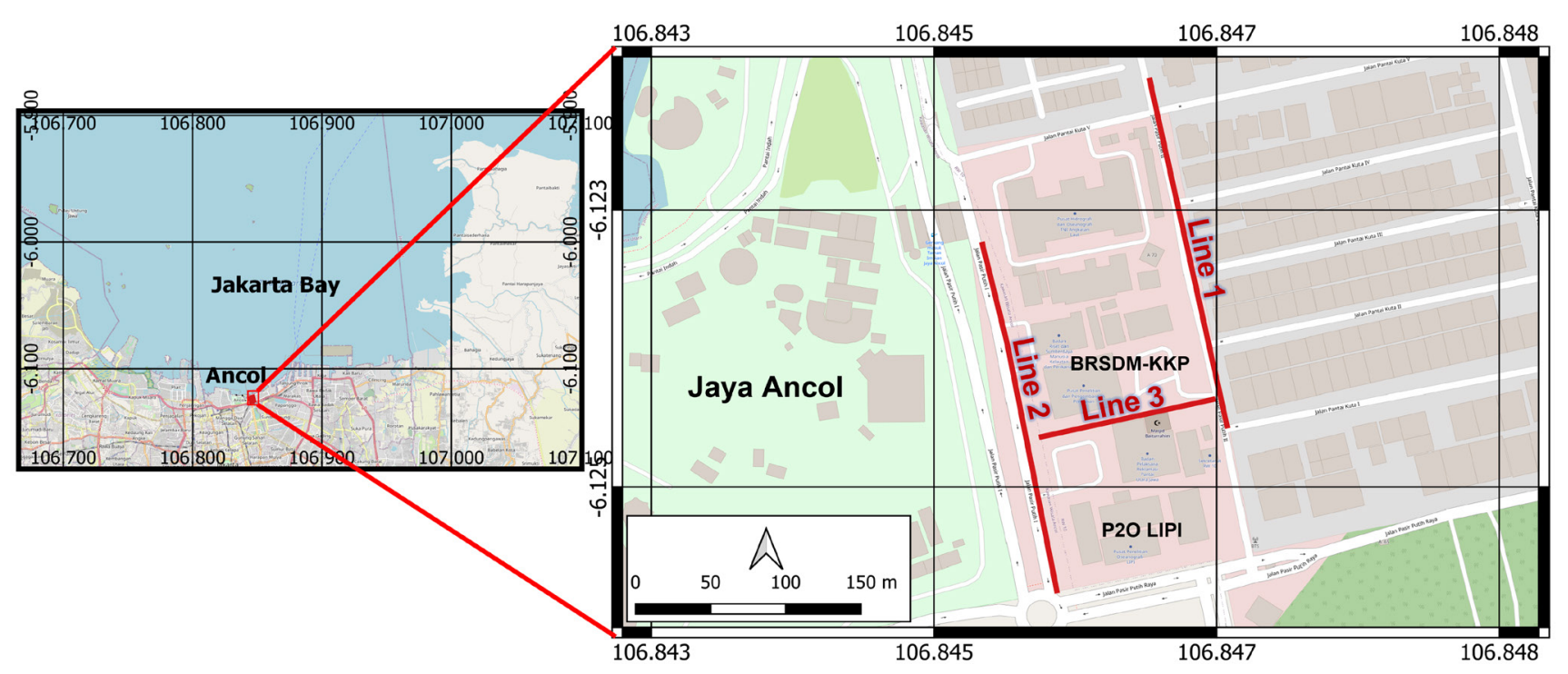

Figure 1. Ancol area and the location of resistivity measurement. 


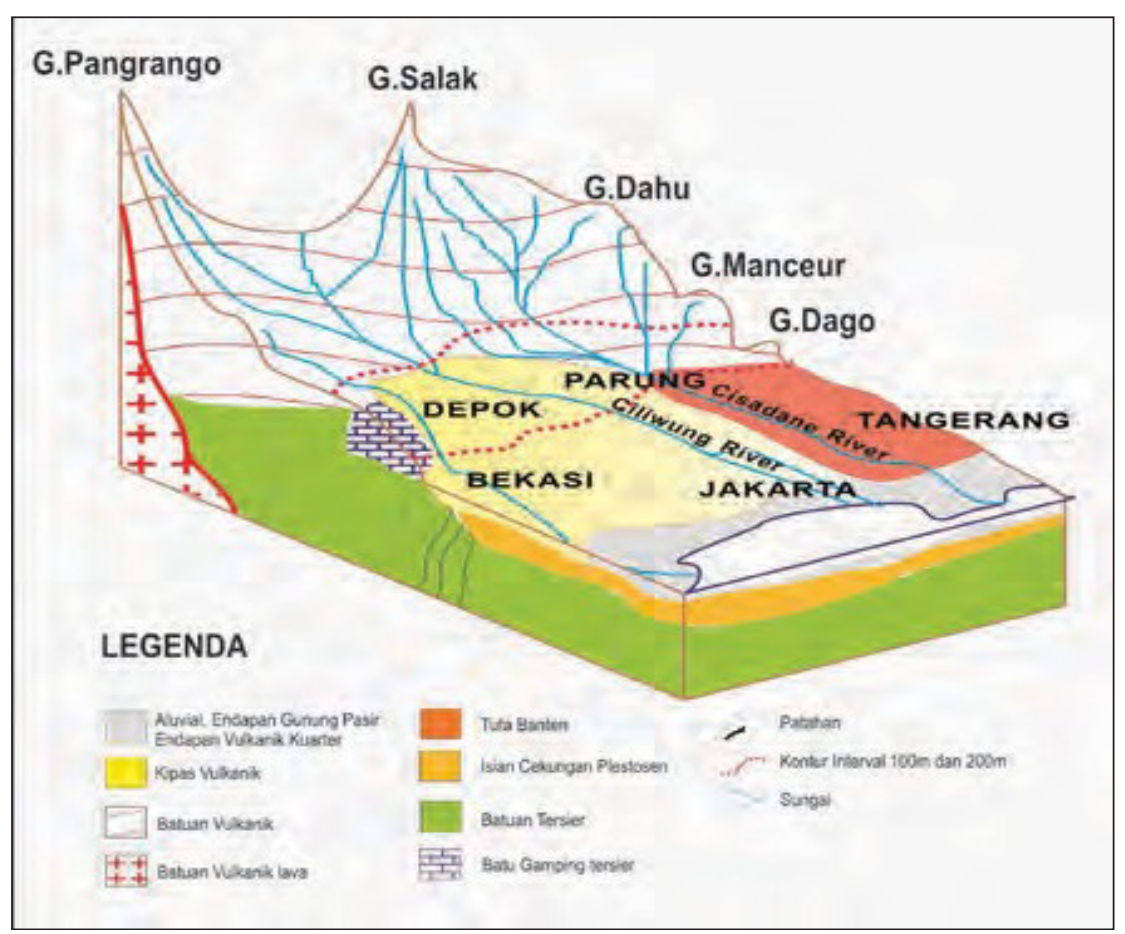

Figure 2. Geological map of Jakarta (Delinom, 2015).

form of volcanic fan deposits resulting from volcanic eruptions south of Jakarta.

Maathius et al. (1996) stated that the geological structure of Jakarta consists of a complex combination of aquifers lens-shaped with clay inserts. Fachri et al. (2002) conducted a hydro stratigraphic study of the Jakarta groundwater basin by grouping aquifer systems. The aquifer zone is dominated by sandstone with high hydraulic conductivity, while the aquitard zone is dominated by claystone with low hydraulic conductivity values. The lithological composition and stratigraphic position can be seen in Figure 3.

\section{Resistivity Method}

The resistivity method is one of the many geophysical methods to estimate earth subsurface conditions. The result of resistivity method is quite good and effective for depicting the soil layer beneath the surface based on differences in the rock resistivity value (Zarroca, 2011; Abdul-Nafiu, 2013). This study used multi-electrode and multi-channel resistivity instruments of MAE X612-EM (Hamzah, 2020) to obtain subsurface $2 \mathrm{D}$ model imaging based on the resistivity value of rock (Nurdiyanto, 2016). The identification of this resistivity imaging is based on the fact that different materials will have different types of resistance values when supplied with an electric current (Wijaya, 2015). The unit of resistivity used is $\Omega \mathrm{m}$ (Ohm.meter) (Hasanudin \& Pryambodo, 2009).

The Coastal reclamation is an effort to utilize areas or land that is relatively useless or still empty and watery into usable land by drying. In other words, reclamation converts coastal waters into land by changing the low ground level and flooded area to higher ground level (Wisnu, 1996). This resistivity imaging will be used to identify the boundaries of

\begin{tabular}{|c|c|c|c|c|}
\hline \multicolumn{2}{|c|}{ UMUR } & STRATIGRAFI & \multirow{2}{*}{\multicolumn{2}{|c|}{$\begin{array}{c}\text { HIDROSTRATIGRAFI } \\
\text { Zona Akuifer } 1\end{array}$}} \\
\hline & Plistosen & \multirow{2}{*}{ Endapan volkanik kuarter $>$ Fm. Citalang } & & \\
\hline \multicolumn{2}{|r|}{ Pliosen } & & Zona Akuifer 2 & $>$ Zona Akuifer 1 \\
\hline & & Fm. Subang & \multirow{3}{*}{\multicolumn{2}{|c|}{ Batuan dasar zona cekungan airtanah }} \\
\hline & \multirow{2}{*}{ Tengah } & Fm. Parigi & & \\
\hline & & Fm. Bojongmanik $\sum$ Fm. Cibulakan & & \\
\hline
\end{tabular}

Figure 3. Jakarta basin hydrostratigraphic column (Fachri et al., 2002). 
reclamation layer in the Ancol area, North Jakarta.

The equipment used in this study is a multichannel resistivity meter from MAE X612-EM to measure the resistivity of rock below the ground level, GPS (Global Positioning System) Garmin type of 78s to determine the position of the measurement, and supporting equipment such as roll meter, calculators, multitester, and handy talky $(\mathrm{HT})$.

The resistivity imaging (2D) identifies resistivity changes in rock types vertically and horizontally below ground level. The electrode configuration used for this measurement is similar to the vertical electrical sounding (VES) or 1D resistivity method but slightly different in data acquisition techniques (Loke, 1999). Data acquisition is performed on a straight track. The number of electrodes 48 with the distance between electrodes is 5 meters, then the length of the measurement line is 240 meters.

The field data acquisition method used in the study is Wenner Configuration, as Figure 2. This method is used to determine the variation of the resistivity laterally and vertically in a particular area. Each line has several measurement points. To obtain the value of apparent resistivity with Wenner configuration, then use formulas such as the equation (1) (Telford, 1990):

$\rho_{a}=K \frac{\Delta V}{I}$

$K=2 \pi a$

Where,

ра = Apparent Resistivity (ohm-m)

$\mathrm{K}=$ Geometry factor
$\Delta \mathrm{V}=$ Electrical Potential $(\mathrm{mV})$

I = Electrical Current (milliAmpere)

a = Distance between the two current electrodes $(A-B)$ dan potential electrodes $(M-N)$

Measurements are performed step by step, starting from a small electrode number and each depth layer $(\mathrm{n})$. After all the data is retrieved and plotted, this data set resembles an overturned boat (Figure 4) (Loke, 2001). In Figure 4, the configuration of the equipment, cables, and the distribution of measurement points against the depth layer are illustrated. After all the data is obtained, then the data processing is carried out. Furthermore, a cross-section of the subsurface resistivity from the taken track is obtained vertically and horizontally.

The study case example is the Wenner configuration electrode with electrode distance "a". The first step is to measure the electrode array 1a, where electrodes numbers $1,2,3$, and 4 are used for measurement. This configuration moves as far as 1a on the layer or $n=1$ until the electrodes number $45,46,47$ and 48. After retrieving the data for spaces $1 \mathrm{a}$ and $n=1$, the next step is to space the electrodes $2 a$ and $n=2$ and use electrodes 1, 3, 5 and 7. Data measurement continues until the electrodes are 41,43,45, and 47 . This process continues down to spaces $5 a$ and $n=5$.

Data measurement was conducted on December 9-10, 2017, in the Ancol area, North Jakarta. The measurement results of the resistivity instrument are stored in a file with the *.DAT extension for each measurement. Furthermore, the data is processed using Res2Dinv software for the inversion process and displays a cross-section image of the subsurface in the form of a $2 \mathrm{D}$ model to help for the interpretation stage.

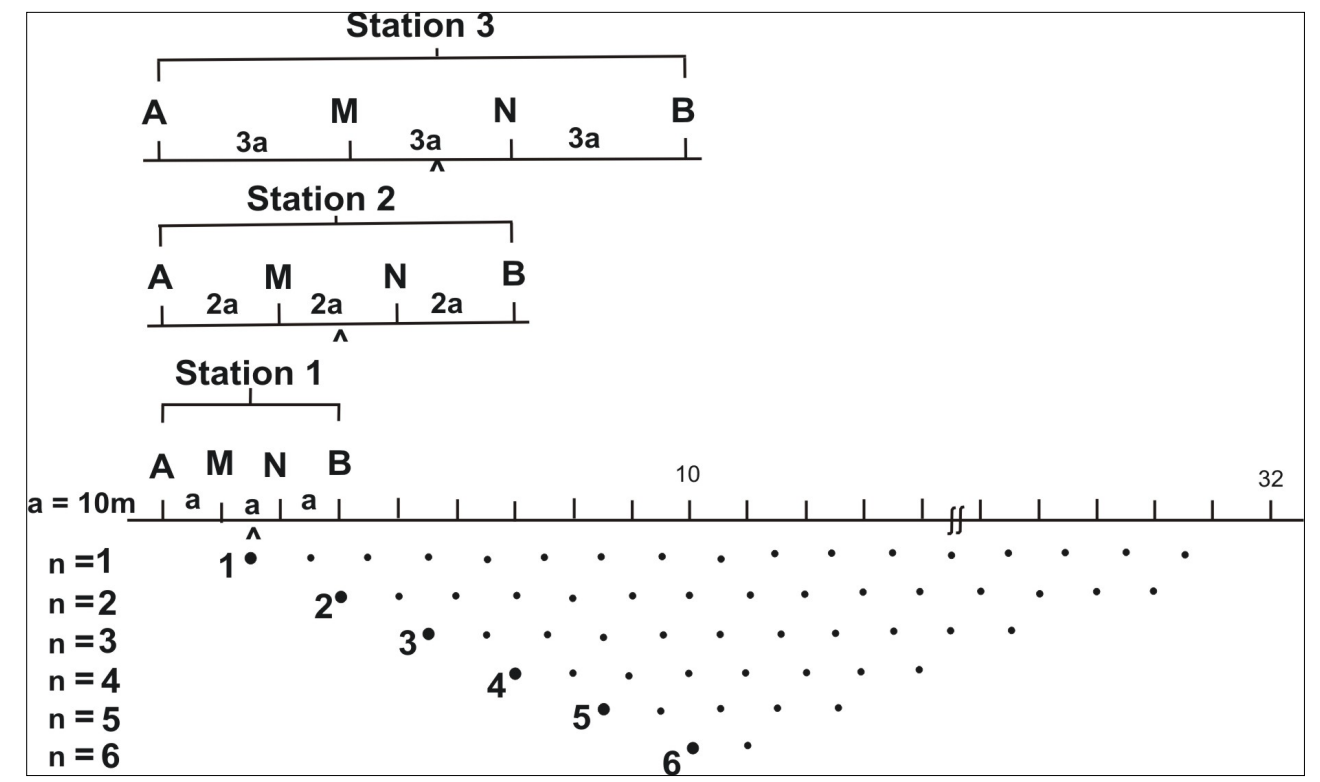

Figure 4. Resistivity imaging data retrieval steps (2D) Wenner configuration (Wijaya, 2015). 


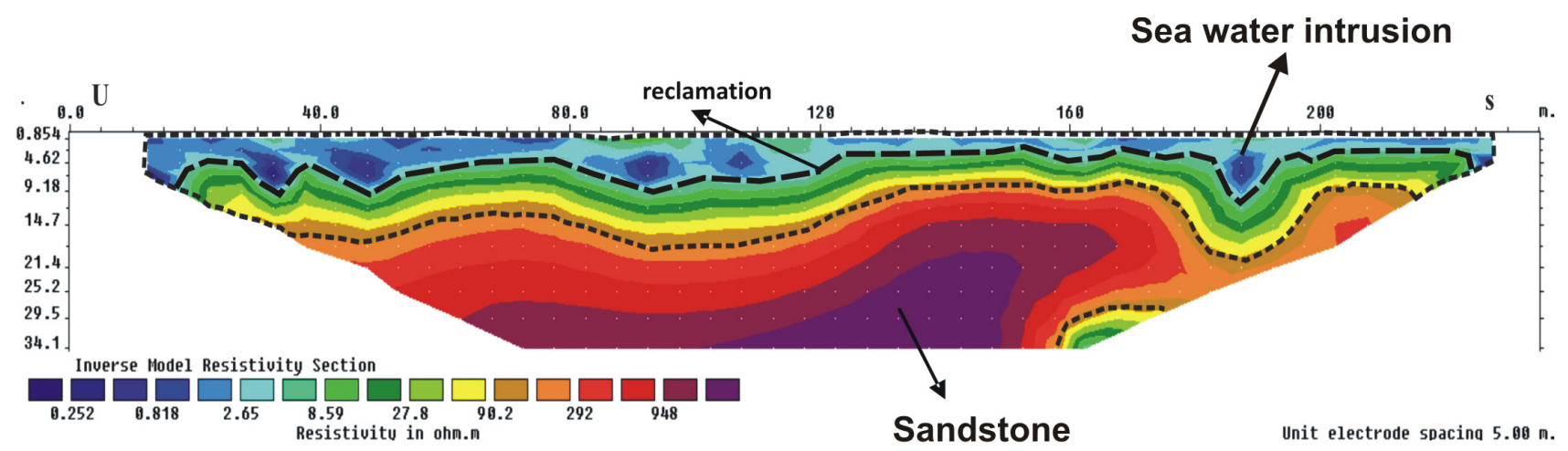

Figure 5. Cross-section of Line 1.

\section{RESULTS AND DISCUSSION}

The result of resistivity measurement in the Ancol area is obtained three resistivity images: Line 1, Line 2 and Line 3 . These resistivity images are shown as a $2 \mathrm{D}$ resistivity cross-section that is interpreted as subsurface lithology to identify reclamation areas. The resistivity measurements for these three locations use a 240-meter stretch of cable with a penetration depth of about 34.1 meters in the subsurface.

\section{Line 1}

Line 1 north-south direction (Figure 1) with a total length of 240 meters located on the Jalan Pasir Putih 2 , Ancol with a penetration depth of about 34.1 meters in the subsurface. The result of this resistivity imaging is shown in Figure 5 that can identify the reclamation layer

Line 1 is composed of alluvium consisting of loose sandy clay (Turkandi, 1992). It is filled with seawater fluid which causes seawater intrusion with a resistivity value $<2.65 \Omega \mathrm{m}$ with a depth of $<10$ meters. The existence of soil filling (reclamation) with a resistivity value of $27.8 \Omega \mathrm{m}$ with a depth of $<4$ meters from the ground surface is also supported by the results of drill and Cone Penetration Test (CPT) data conducted by the Trisakti University Research Institute in 1999 which states the existing residential complex area in the
North Jakarta areas such as Pantai Indah Kapuk, Pluit, Ancol, Kelapa Gading and Sunter have experienced backfill ranging from 1-3 meters. The fill material used is generally in red soil (volcanic weathering) and partly in the form of building debris. The resistivity value $>292 \Omega \mathrm{m}$ is in the form of sandstone units of the Kaliwangu Formation, which leads south - north of the Jakarta groundwater basin (Delinom, 2015). The presence of groundwater is indicated by a resistivity value of $90.2 \Omega \mathrm{m}$ with a depth of about 14 meters. This groundwater's constituent rock is thin sand leading from south to north, following the direction of the Jakarta groundwater basin.

\section{Line 2}

The Line 2 is on Jalan Pasir Putih 1, Ancol and is 115 meters east of Pasir Putih 2 road. Line 2 is north-south (Figure 6) with a length of 240 meters and a penetration depth of about 34.1 meters in the subsurface.

On Line 2, there is an indication of seawater intrusion with a depth of more than 20 meters to the north of this Line with a resistivity value of $<2.65$ $\Omega \mathrm{m}$. This seawater intrusion is caused by seawater inundation in a flood pump area at the northern end of this Line. The reclamation results are also observed with a resistivity value of $27.8 \Omega \mathrm{m}$ with a depth of less than 4 meters. The presence of groundwater is visible

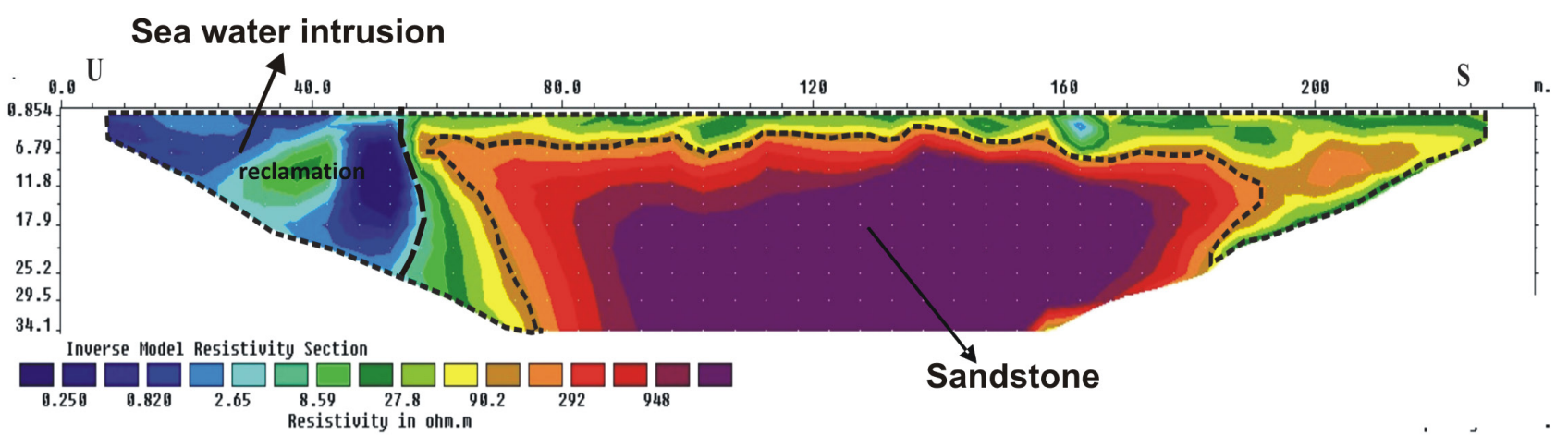

Figure $6 . \quad$ Cross-section of Line 2. 


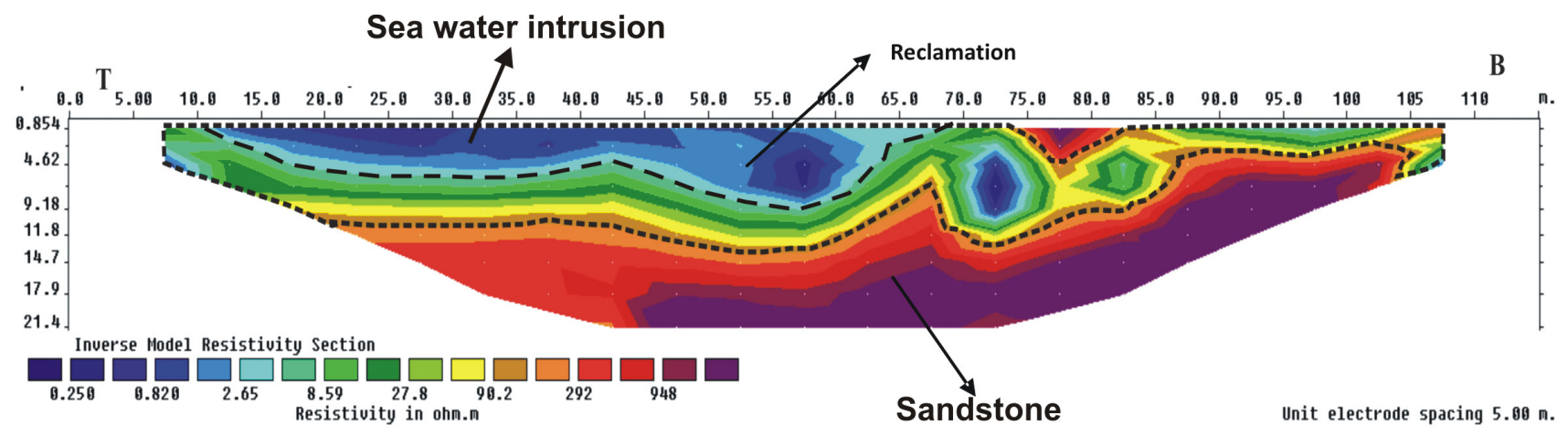

Figure 7. Cross-section of Line 3.

in the south of this Line with a resistivity value of 90.2 $\Omega m$ with a shallower depth than Line 1 at a depth of 5 meters above ground level in a south-north direction from the Jakarta groundwater basin. The hard rock with a resistivity value of $>292 \Omega \mathrm{m}$ is sandstone from the Kaliwangu formation with a depth of about 11 meters above ground level.

\section{Line 3}

Line 3 is a cross line connecting Line 1 and Line 2. This Line spreads for 115 meters in a WestEast direction (Figure 7) with an imaging depth of 21.4 meters above ground level. The result of the resistivity imaging of line 3 is a transverse line that connects between line 1 (Jl. Pasir Putih 2) and line 2 (Jl. Pasir Putih 1),

Seawater intrusion is observed to the east of this line, which is around the Jl. Pasir Putih 2, with a depth of almost 5 meters marked with a resistivity value of $<2.65 \Omega \mathrm{m}$. This agrees with Line 1 , where seawater intrusion is also around a depth of almost 5 meters. The resistivity value of $27.8 \Omega \mathrm{m}$ indicates reclamation at a depth of less than 4 meters seen on the west side of Line 3 . The aquifer on this line with a resistivity value of $90.2 \Omega \mathrm{m}$ is observed to the west with a depth of about 6 meters. The hard rock with a resistivity value $>292 \Omega \mathrm{m}$ that is supposed to be sandstone is slightly shallow to the west, and it corresponds to Line 2 (Jl. Pasir Putih 1).

Based on the results of subsurface identification using the resistivity method in the study area, there are four classifications based on the resistivity value: seawater intrusion, reclamation, aquifer, and hard rock (sandstone), as shown in Table 1.

Based on the results of 2D resistivity identification, almost the entire upper surface of the study area is reclamation area. It is characterized by a relatively low resistivity value of $<27.8 \Omega \mathrm{m}$ that indicates an uncompacted backfill in an average depth of less than four meters. This low resistivity is caused by the void between the grains of uncompacted backfill is filled by seawater and cause seawater intrusion to appear with a resistivity value $<2.65 \Omega \mathrm{m}$. Shallow aquifers from groundwater are found at a depth of about $6-10$ meters below the ground surface with a sandy lithology from the Kaliwangu formation with a resistivity value of $27.8-90.2 \Omega \mathrm{m}$. The hard rock from this research area is sandstone with a resistivity value $>292 \Omega \mathrm{m}$. This hard rock is slightly shallow on Line 2 (Jl. Pasir Putih 1). Therefore, it is suitable to be built with heavy loads (high buildings) because the foundations of high buildings will reach this hard rock and decrease subsidence.

\begin{tabular}{lll}
\hline No & Resistivity of Rock $(\Omega \mathrm{m})$ & Classification \\
\hline 1 & $<2.65$ & Sea Water Intrusion \\
2 & $8.9-27.8$ & Reclamation \\
3 & $27.8-90.2$ & Aquifer \\
4 & $>292$ & Hardrock (Sandstone) \\
\hline
\end{tabular}




\section{CONCLUSION}

This study describes the application of the 2D resistivity method to identify the reclamation layer in the Ancol area. The results show that subsurface imaging gives a good response by showing a small resistivity value $<27.8 \Omega \mathrm{m}$ which is identified as a reclamation area in the almost study area with a reclamation depth of less than four meters. Beneath the reclamation layer, hard rock with a resistivity value of $>292 \Omega \mathrm{m}$ and is supposed to be sandstone as the bedrock in the Ancol area. This hard rock is shallow on Line 2 (Jl. Pasir Putih 1), and there are high buildings on Line 2 (Jl. Pasir Putih 1). Therefore when constructing a building with a heavy load, the foundation of the building must reach these hard rocks. Thus, the building does not collapse because the results of this reclamation are composed of loose rocks that have not been fully compacted (reclamation), so that it has not been fully consolidated. As a result, if subjected to an excessive load, the soil will experience subsidence or collapse.

\section{ACKOWLEDGEMENTS}

We would like to express our gratitude to the head of the marine research center BRSDM KP for the assistance and facilities provided. Finally, to the editorial board of SEGARA and the reviewers, we also thank you for your cooperation until this paper can be published. Dino Gunawan Pryambodo and Joko Prihantono were the main contributors

\section{REFFERENCE}

Abdul-Nafiu, A.K., Nawawi, M.M.N., Khiruddin, A, Ishola, K.S., \& Abdulrahman, A. (2013). Effects of Electrode Spacing and Inversion Techniques on the Efficiency of 2D Resistivity Imaging to Delineate Subsurface Features. American Journal of Applied Sciences, 10(1), 64-72.

Amien, S. (2016, in Indonesian). Hydrogeological Investigation Using the Schlumberger Geoelectric Method in Hamparan Perak District, Deli Serdang, North Sumatra. Journal of Electrical Technology, 1(2), 22-26.

Barker, R.D. (1981). The offset system of electrical resistivity sounding and its use with a multicore cable. Geophysical Prospecting, 29(1), 128-143.

Delinom, R,M. (2015, in Indonesian). Jakarta's Subsurface Threats are Invisible, Unthinkable, and Unexpected. LIPI Press, pp.313.

Edyanto, C.B.H. (2016, in Indonesian). Factors that influence the reclamation process to anticipate disasters in the coastal environment. Jurnal Sains dan Teknologi Mitigasi Bencana, 11(1), 1-11.

Fachri, M., Djuhaeni, L.M. Hutasoit, A.M. Ramdhan., (2002, in Indonesian). Stratigraphy and Hydrostratigraphy of the Jakarta Groundwater Basin. Buletin Geologi, 34(3), 169-190.

Gunawan, R. (2010, in Indonesian). Toponym Jakarta and the Thousand Islands, Ministry of Culture and Tourism, Jakarta.

Hamzah, A. (2020, in Indonesian). MAE X612EM GEOELECTRIC GUIDE. Fakultas Teknik Sipil, Perencanaan, dan Kebumian. ITS. Surabaya.

Hasanudin, M., \& Pryambodo. D.G. (2009,in Indonesian). Study of Seawater Intrusion in Cirebon Using Geoelectric Method. Jurnal Segara, 5(2), 121-133.

Lembaga Penelitian Universitas Trisakti. (1999, in Indonesian). Study of engineering geology/soil bearing capacity in North Jakarta and Central Jakarta, Jakarta.

Loke, M.H, (1999). Electrical Imaging Surveys for Environmental and Engineering Studies, Technical Notes. Geotomo Software, Malaysia.

Loke, M,H. (2001). Tutorial 2-D and 3-D electrical Imagine Survey, Geotomo Software, Malaysia.

Maathius, H., Young, R.N., Adi, S., \& Prawiradisastra, S. (1996). Final Report : Development of Groundwater Management Srategis in the Coastal Region of Jakarta. SRC Publication No. R-1250-I-E-96.

Martodjojo, S. (1984, in Indonesian). The Evolution of the Bogor Basin, West Java. Desertasi S3. Institute Teknologi Bandung, unpublished, Bandung.

Nurdiyanto, B., Suyanto, I., Sunardi, B., \& Susilanto, P. (2016, in Indonesian). TGeoelectric Tomography for Lithological Identification of Weir and Tunnel Planned Locations in North Sulawesi. JURNAL METEOROLOGI DAN GEOFISIKA, 17(1), 15-23.

Palacky, G.J. (1987) Resistivity characteristics of geologic targets", In Electromagnetic Methods in Applied Geophysics Theory, vol. 1. Society of Exploration Geophysicists.

Permen 40 of 2007 concerning guidelines for spatial planning of coastal reclamation areas, DEPARTMENT OF PUBLIC WORKS DIRECTORATE GENERAL OF SPATIAL 


\section{PLANNING}

Suharto, W. (1996). Coastal Reclamation in Water Management Perspective, Semarang, Unika Soegijapranata.

Turkandi, T., Sidarto, D., Agustyanto, A., \& Hadiwidjoyo, M.M.P. (1992, in Indonesian). Geological Map Sheet Jakarta and the Thousand Islands, Java, Geological Research and Development Center, Bandung.

Telford, W.M., Geldart, L.P., \& Sheriff, R.E. (1990). Applied Geophysics, Second Edition, Cambridge and Hall, New York,

Wijaya, A.S. (2015, in Indonesian). Application of the Wenner Configuration Resistivity Geoelectric Method to Determine Soil Structure in the Backyard of SCC ITS Surabaya. Jurnal Fisika Indonesia, 19(55), 1-5.

Zarroca, M., Bach, J., Linares, R., \& Pellicer, X.M. (2011). Electrical methods (VES and ERT) for identifying, mapping and monitoring different saline domains in a coastal plain region (Alt Empordà, Northern Spain). Journal of Hydrology, 409(1-2), 407-422. 